\title{
To study the effect of natural enemy Trichogramma chilonis (Ishii) against spotted bollworm (Earias Vittella F.) on okra
}

\author{
Sher Ahmed ${ }^{1 *}$, Sarfraz Ahmed ${ }^{2}$, Munir Ahmad Khetran ${ }^{1}$, Safeer \\ Ahmed $^{3}$, Shahzad Ahmed Shahwani ${ }^{3}$, Mohammad Amin ${ }^{4}$ and \\ Muhammad Iqbal Jakhro ${ }^{1}$ \\ 1. PARC, Balochistan Agricultural Research and Development Centre Brewery Road, Quetta-Pakistan \\ 2. Department of Entomology, Sindh Agriculture University, Tandojam-Pakistan \\ 3. Balochistan Agriculture College, Quetta-Pakistan \\ 4. Department of Entomology, University of Poonch, Rawalakot, Azad Jammu and Kashmir-Pakistan \\ *Corresponding author's email: sherbardc@gmail.com

\section{Citation}

Sher Ahmed, Sarfraz Ahmed, Munir Ahmad Khetran, Safeer Ahmed, Shahzad Ahmed Shahwani, Mohammad Amin and Muhammad Iqbal Jakhro. To study the effect of natural enemy Trichogramma chilonis (Ishii) against spotted bollworm (Earias Vittella F.) on okra. Pure and Applied Biology. Vol. 7, Issue 2, pp655-661. http://dx.doi.org/10.19045/bspab.2018.70081

Received: 01/02/2018 Revised: 09/05/2018
Accepted: $15 / 05 / 2018$

Online First: 17/05/2018

\section{Abstract}

The present study was conducted at the Pussia Goth near Tandojam during the year 2016, to study the effect of natural enemy Trichogramma chilonis (Ishii.) against spotted bollworm (Earias Vittella Fabricius) on okra. Observations on spotted bollworm population were recorded at once per week. Pre-treatment observation was recorded one day before release and post-treatment observation was recorded three and five days after release. The reduction percentage was also calculated. The maximum population of spotted bollworm recorded in $6^{\text {th }}$ week was $(17.66 \pm 1.72)$ and minimum population in $10^{\text {th }}$ week was $(14.33 \pm 0.29)$ in control plot during $1^{\text {st }}$ to $10^{\text {th }}$ weeks duration, respectively. The natural enemies were released at the interval of 10 days. However, the population in treated plot after 3 days of ( $T$. chilonis) releases the maximum population of spotted bollworm was recorded in $2^{\text {nd }}$ week $(8.89 \pm 1.24)$ and minimum population in $10^{\text {th }}$ week $(6.19 \pm 0.29)$ during $1^{\text {st }}$ to $10^{\text {th }}$ week duration, respectively. Peak level of spotted bollworm was observed during $1^{\text {st }}$ and $2^{\text {nd }}$ weeks afterward the spotted bollworm population was declined in a linear sequence from $3^{\text {rd }}$ to $10^{\text {th }}$ weeks. Similarly, after 5 days ( $T$. chilonis) releases, the maximum population of spotted bollworm was recorded in $1^{\text {st }}$ week $(10.16 \pm 1.33)$ and minimum population in $10^{\text {th }}$ week $(8.00 \pm 0.41)$ during $1^{\text {st }}$ to $10^{\text {th }}$ week duration, respectively. Peak level of spotted bollworm was observed during $1^{\text {st }}$ and $2^{\text {nd }}$ weeks afterward the spotted bollworm population was declined in a linear sequence from $3^{\text {rd }}$ to $10^{\text {th }}$ weeks. Moreover, the results showed that spotted bollworm populations were considerably declined in treated plots due to the presence of T. chilonis as compare to control plot.

Keywords: Biological agent; Okra; Population; Spotted bollworm

Introduction

Okra, Abelmoschus esculentus (L.) belongs to family Malvaceae is Kharif season vegetable as well as cash crop of Pakistan. It is originated from Africa and Asia. This is famous vegetable used as human food in the 
country with great interest. This vegetable almost grown throughout the world during warm season [1-3]. A number of factors which influenced the productivity of okra crop. Among them, insect pests are the major factor which destroyed the okra crop and produced almost 69 percent damaged in yield losses [4, 5]. Among insects, bollworms, spotted bollworms and American bollworms are dominant pests which damaged the okra in early and late developmental stages. The magnitude of infestation and the nature of extent of injury vary with plant variety, seasons and localities [5]. Despite massive applications of broad-spectrum insecticides, the action of natural enemies plays an important role in reducing insect pest infestation, both through inundative releases or as natural control agents [6]. Biological control is often viewed as a promising alternative or complement to pesticides in integrated pest management programs [7]. The successes and failures of biological control have been extensively reviewed [8]. Factors that can influence the effectiveness of biological control agents include agent specificity (generalist or specialist), the type of agent (predator, parasitoid, or pathogen), the timing and number of releases, the method of release, synchrony of the natural enemy with the host, field conditions, and release rate [9]. The use of Trichogramma species as biocontrol agent is a recognized alternate of insecticides throughout the world. Trichogramma chilonis (Ishii) in Pakistan parasitizes the egg of Acigona steniellsu (Hanps.), Agrotis ipsilon (Hfn.), Autographa nigrisigna (Walk.), Chilo infuscatellus (Sn.), C. partellus (Swinh.), Emmalocera depressella (Swinh.), Heliothis armigera (Hbn.), and Spodoptera litura (F.) indicating its potential for biological control of these insect pests [10]. Trichogramma chilonis Ishii (Hymenoptera: Trichogrammatidae) are minute polyphagous wasps, commonly recognized as 'stingless wasps. It has been used in sugarcane, corn, cotton, vegetables and fruits crops as bio-agent for the control of lepidopterous pests in more than 32 million hectares each year around the world for the control of pests since 20 years. The release of T. chilonis in China, Switzerland, Canada and former USSR reduced the damage up to 70 to $92 \%$ on sugarcane [11]. These tiny parasitoids lay their eggs in eggs of other species. Trichogramma represent around 80 genera from the Trichogrammatidae family with over 800 species worldwide [12-15]. Keeping in view the above facts and figures this study was conducted to equate the efficacy of Trichogramma chilonis against spotted bollworm (Earias Vittella F.) on okra.

\section{Materials and methods}

The experiment was carried out at the experimental area of Pussia Goth near Tandojam during 2016 to monitor the effect of natural enemy Trichogramma chilonis (Ishii.) against spotted bollworm of okra. The variety (Sabzpari) of okra was sown on area of 106' x 66' ft. By drilling method of sowing with all other agronomical practices were carried out as usual for this experiment. Observations on spotted bollworm population were recorded once per week. Six releases were made during the cropping season at the rate of 6 cards per acre. Trichogramma were released (as pupae) inside the host eggs ready to emerge as adults and they were glued to cards. Trichogramma wasps were emerged from cards in two to five days. Selected five plants for each treatment for recording spotted bollworm population and 05 leaves were observed from top, middle and bottom for spotted bollworm infestation. Pre-treatment observation was recorded one day before release and Posttreatment observations were recorded 3 and 5 days after release.

\section{Calculating reduction percentage}

The reduction percentage was calculated according [16] by the following formula: 


\section{$\mathrm{Ta} \quad \mathrm{Cb}$ \\ Percentage Mortality =1 ----------X---------- x 100 \\ $\mathrm{Ca} \mathrm{Tb}$ \\ Mean population of spotted bollworm on okra crop after Trichogramma chilonis cards releases}

Where,

$\mathrm{Tb}=$ Number of spotted bollworm in the treated plots before treatment.

$\mathrm{Ta}=$ Number of spotted bollworm in the treated plots after treatment.

$\mathrm{Cb}=$ Spotted bollworm population in the control plots before treatment.

$\mathrm{Ca}=$ Spotted bollworm population in the control plots after treatment.

The data of pests and natural enemies were also recorded from control plot for comparison. Collected data were interpreted in spreadsheet of Microsoft excel. Then further data analysis ANOVA was carried out through software Statistix 8.1 [17].

\section{Results and discussion}

In order to study the effect of natural enemy Trichogramma chilonis (Ishii.) against spotted bollworm of okra, the experiment was carried out at the Pussia Goth near Tandojam during the year 2016. The results are presented in (Table 1,2,3) their analysis of variance as shown as (Table 4,5).
The data (Table 1) indicated that spotted bollworm population in control plot was counted as $16.32 \pm 1.41, \quad 16.33 \pm 1.24$, $17.32 \pm 1.87, \quad 14.47 \pm 1.76, \quad 14.98 \pm 1.75$, $17.66 \pm 1.72, \quad 15.32 \pm 1.58, \quad 16.52 \pm 1.51$, $16.21 \pm 1.46$ and $14.33 \pm 0.29$ during $1^{\text {st }}, 2^{\text {nd }}$, $3^{\text {rd }}, 4^{\text {th }}, 5^{\text {th }}, 6^{\text {th }}, 7^{\text {th }}, 8^{\text {th }}, 9^{\text {th }}$ and $10^{\text {th }}$ weeks duration, respectively. The population of spotted bollworm in okra crop was observed as zigzag trend in control plot (where no biological control) was applied. The data further demonstrated that the observation between weeks was found non-significant ( $\mathrm{P}>0.05)$ difference in spotted bollworm population in okra crop. The maximum population was recorded in $6^{\text {th }}$ week $(17.66 \pm 1.72)$ of observation and minimum population of spotted bollworm was observed in $10^{\text {th }}$ week $(14.33 \pm 0.29)$ in control plot.

Table 1. Mean population of spotted bollworms in control plot on okra crop

\begin{tabular}{|c|c|}
\hline Observation weeks & Pest population of control plot \\
\hline $1^{\text {st }}$ & $16.32 \pm 1.41 \mathrm{ab}$ \\
\hline $2^{\text {nd }}$ & $16.33 \pm 1.24 \mathrm{ab}$ \\
\hline $3^{\text {rd }}$ & $17.32 \pm 1.87 \mathrm{a}$ \\
\hline $4^{\text {th }}$ & $14.47 \pm 1.76 \mathrm{bcd}$ \\
\hline $5^{\text {th }}$ & $14.98 \pm 1.75 \mathrm{bcd}$ \\
\hline $6^{\text {th }}$ & $17.66 \pm 1.72 \mathrm{a}$ \\
\hline $7^{\text {th }}$ & $15.32 \pm 1.58 \mathrm{bc}$ \\
\hline $8^{\text {th }}$ & $16.52 \pm 1.51 \mathrm{ab}$ \\
\hline $9^{\text {th }}$ & $16.21 \pm 1.46 \mathrm{ab}$ \\
\hline $10^{\text {th }}$ & $14.33 \pm 0.29 \mathrm{bcd}$ \\
\hline Mean \pm S.E & $\mathbf{1 5 . 9 5} \pm \mathbf{1 . 4 6}$ \\
\hline
\end{tabular}

Values in the column with same letters did not differ significant at P-value $<0.05$

The data (Table 2) showed that spotted bollworm population in Pre-treatment plot was counted as $14.42 \pm 2.58,15.50 \pm 2.56$, $13.38 \pm 1.51, \quad 13.98 \pm 2.05, \quad 15.06 \pm 2.34$, $12.56 \pm 1.53, \quad 14.40 \pm 2.60, \quad 15.02 \pm 2.40$,
$15.82 \pm 2.48$ and $13.56 \pm 2.24$ during $1^{\text {st }}, 2^{\text {nd }}$, $3^{\text {rd }}, 4^{\text {th }}, 5^{\text {th }}, 6^{\text {th }}, 7^{\text {th }}, 8^{\text {th }}, 9^{\text {th }}$ and $10^{\text {th }}$ weeks duration, respectively. The population of spotted bollworm in okra crop was observed as crisscross trend in control plot (where no 
biological control) was applied. The data further demonstrated that the observation between weeks was found non-significant $(\mathrm{P}>0.05)$ difference in spotted bollworm population in okra crop. The maximum population was recorded in $9^{\text {th }}$ week (15.82 \pm 2.48$)$ of observation and minimum population of spotted bollworm was observed $(12.56 \pm 1.53)$ in $6^{\text {th }}$ week in pre-treatment plot. However, the results regarding spotted bollworm population in treated plot after 3 days of Trichogramma chilonis(Ishii.) cards releases was counted as $8.23 \pm 1.41$, $8.89 \pm 1.24,7.89 \pm 1.87,7.94 \pm 1.76,7.87 \pm 1.75$, $7.79 \pm 1.72,6.78 \pm 1.58,6.75 \pm 1.51,6.24 \pm 1.46$ and $6.19 \pm 0.29$ during $1^{\text {st }}, 2^{\text {nd }}, 3^{\text {rd }}, 4^{\text {th }}, 5^{\text {th }}, 6^{\text {th }}$, $7^{\text {th }}, 8^{\text {th }}, 9^{\text {th }}$ and $10^{\text {th }}$ weeks duration, respectively. Peak level of spotted bollworm was observed during $1^{\text {st }}$ and $2^{\text {nd }}$ weeks afterward the spotted bollworm population was declined in a linear sequence from $3^{\text {rd }}$ to $10^{\text {th }}$ weeks. Moreover, statistical analysis showed significant $(\mathrm{P}<0.05)$ difference in spotted bollworm population between the different observation weeks in okra crop. The maximum population was recorded in $2^{\text {st }}$ week $(8.89 \pm 1.24)$ of observation and minimum population of spotted bollworm

Table 2. Mean population of spotted bollworm on okra crop after Trichogramma chilonis (Ishii.) cards releases on different weeks

\begin{tabular}{|c|c|c|c|}
\hline \multirow{2}{*}{$\begin{array}{c}\text { Observation } \\
\text { weeks }\end{array}$} & $\begin{array}{c}\text { Pre-treatment } \\
\text { observations }\end{array}$ & \begin{tabular}{c}
$|c|$ \\
3 Days After \\
\cline { 3 - 4 }
\end{tabular} & $\begin{array}{c}\text { Trichogramma releases } \\
\text { Trichogramma releases }\end{array}$ \\
\hline $1^{\text {st }}$ & $14.42 \pm 2.58 \mathrm{ab}$ & $8.23 \pm 1.41 \mathrm{a}$ & $10.86 \pm 1.71 \mathrm{a}$ \\
\hline $2^{\text {nd }}$ & $15.50 \pm 2.56 \mathrm{a}$ & $8.89 \pm 1.24 \mathrm{ab}$ & $10.16 \pm 1.33 \mathrm{ab}$ \\
\hline $3^{\text {rd }}$ & $13.38 \pm 1.51 \mathrm{ab}$ & $7.89 \pm 1.87 \mathrm{ab}$ & $9.98 \pm 1.97 \mathrm{ab}$ \\
\hline $4^{\text {th }}$ & $13.98 \pm 2.05 \mathrm{ab}$ & $7.94 \pm 1.76 \mathrm{abc}$ & $9.82 \pm 1.51 \mathrm{abc}$ \\
\hline $5^{\text {th }}$ & $15.06 \pm 2.34 \mathrm{ab}$ & $7.87 \pm 1.75 \mathrm{abcd}$ & $9.77 \pm 1.43 \mathrm{abcd}$ \\
\hline $6^{\text {th }}$ & $12.56 \pm 1.53 \mathrm{~b}$ & $7.79 \pm 1.72 \mathrm{abcd}$ & $9.62 \pm 1.63 \mathrm{abcd}$ \\
\hline $7^{\text {th }}$ & $14.40 \pm 2.60 \mathrm{ab}$ & $6.78 \pm 1.58 \mathrm{bcd}$ & $8.81 \pm 1.50 \mathrm{bcd}$ \\
\hline $8^{\text {th }}$ & $15.02 \pm 2.40 \mathrm{ab}$ & $6.75 \pm 1.51 \mathrm{bcd}$ & $8.69 \pm 0.72 \mathrm{bcd}$ \\
\hline $9^{\text {th }}$ & $15.82 \pm 2.48 \mathrm{a}$ & $6.24 \pm 1.46 \mathrm{~cd}$ & $8.20 \pm 0.71 \mathrm{~cd}$ \\
\hline $10^{\text {th }}$ & $13.56 \pm 2.24 \mathrm{ab}$ & $6.19 \pm 0.29 \mathrm{~d}$ & $8.00 \pm 0.41 \mathrm{~d}$ \\
\hline T-value & $\mathbf{4 4 . 5 9}$ & $\mathbf{2 1 . 6 4}$ & $\mathbf{3 3 . 2 5}$ \\
\hline
\end{tabular}

Values in the column with same letters did not differ significant at P-value $<0.05$ 
Reduction percentage of spotted bollworm The data (Table 3 ) indicated that $59.89 \%$ and $66.65 \%$ reduction was examined in treated plots after three and five days Trichogramma chilonis (Ishii.) cards releases respectively as compare to control (untreated) plot. It was observed that Trichogramma chilonis (Ishii.) is useful biological agent for integrated pest management program.

Table 3. Reduction percentage of spotted bollworm of okra crop after three and five days Trichogramma chilonis (Ishii.) cards releases

\begin{tabular}{|c|c|c|c|c|c|}
\hline $\begin{array}{c}\text { Name of } \\
\text { Specie }\end{array}$ & $\begin{array}{c}\text { Population } \\
\text { in control } \\
\text { plot }\end{array}$ & $\begin{array}{c}\text { Population in } \\
\text { treated plot after } \\
\text { 3 days }\end{array}$ & $\begin{array}{c}\text { Reduction } \\
(\%)\end{array}$ & $\begin{array}{c}\text { Population in } \\
\text { treated plot } \\
\text { after 5 days }\end{array}$ & $\begin{array}{c}\text { Reductio } \\
\text { n (\%) }\end{array}$ \\
\hline $\begin{array}{c}\text { Spotted } \\
\text { bollworm }\end{array}$ & 647.21 & 387.65 & 59.89 & 431.38 & 66.65 \\
\hline
\end{tabular}

Table 4. One sample t-test for spotted bollworm population after 3 days Trichogramma chilonis (Ishii.) cards releases

\begin{tabular}{|c|c|c|c|c|c|c|c|}
\hline \multicolumn{8}{|c|}{ 95\% confidence interval } \\
\hline Variable & Mean & SE & Lower & Upper & T & DF & P \\
\hline Control plot & 11.232 & 0.2073 & 7.9231 & 10.614 & 48.21 & 49 & 0.0000 \\
\hline $\begin{array}{c}\text { After 3 days } \\
\text { chilonis cards } \\
\text { releases }\end{array}$ & 14.465 & 0.3241 & 16.648 & 16.116 & 48.51 & 49 & 0.0000 \\
\hline
\end{tabular}

Table 5. One sample t-test for spotted bollworm population after 5 days Trichogramma chilonis cards (Ishii.) releases

\begin{tabular}{|c|c|c|c|c|c|c|c|}
\hline \multicolumn{8}{|c|}{ 95\% confidence interval } \\
\hline Variable & Mean & SE & Lower & Upper & T & DF & P \\
\hline Control plot & 11.232 & 0.2073 & 7.9231 & 10.614 & 48.21 & 49 & 0.0000 \\
\hline $\begin{array}{c}\text { After 5days T. chilonis } \\
\text { cards releases }\end{array}$ & 15.611 & 0.3310 & 15.604 & 16.185 & 47.65 & 49 & 0.0000 \\
\hline
\end{tabular}

Farmers mainly rely on insecticides for the management of insect pests. Insecticides are costly and indiscriminate use has induced insect resistance to the insecticides and caused environmental pollution [18]. The magnitude of infestation and the nature of extent of injury vary with plant variety, seasons and localities [19]. The use of Trichogramma species as bio-control agent is a recognized alternate of insecticides throughout the world indicating its potential for biological control of these insect pests [10]. Trichogramma chilonis Ishii (Hymenoptera: Trichogrammatidae) are minute polyphagous wasps, commonly recognized as stingless wasps. The results showed that spotted bollworm population in control plot was counted as $16.32 \pm 1.41$, $16.33 \pm 1.24, \quad 17.32 \pm 1.87, \quad 14.47 \pm 1.76$, $14.98 \pm 1.75, \quad 17.66 \pm 1.72, \quad 15.32 \pm 1.58$, $16.52 \pm 1.51, \quad 16.21 \pm 1.46$ and $14.33 \pm 0.29$ during $1^{\text {st }}, 2^{\text {nd }}, 3^{\text {rd }}, 4^{\text {th }}, 5^{\text {th }}, 6^{\text {th }}, 7^{\text {th }}, 8^{\text {th }}, 9^{\text {th }}$ and $10^{\text {th }}$ weeks duration, respectively. However, the results regarding spotted bollworm population in Trichogramma chilonis treated plot after 3 days was counted as $8.23 \pm 1.41$, $8.89 \pm 1.24, \quad 7.89 \pm 1.87, \quad 7.94 \pm 1.76$, $7.87 \pm 1.75, \quad 7.79 \pm 1.72, \quad 6.78 \pm 1.58$, $6.75 \pm 1.51,6.24 \pm 1.46$ and $6.19 \pm 0.29$ during $1^{\text {st }}, 2^{\text {nd }}, 3^{\text {rd }}, 4^{\text {th }}, 5^{\text {th }}, 6^{\text {th }}, 7^{\text {th }}, 8^{\text {th }}, 9^{\text {th }}$ and $10^{\text {th }}$ 
weeks duration, respectively. Similarly, after 5 days Trichogramma chilonis (Ishii.) releases, the results indicated that spotted bollworm population was counted as $10.86 \pm 1.71, \quad 10.16 \pm 1.33, \quad 9.98 \pm 1.97$, $9.82 \pm 1.51, \quad 9.77 \pm 1.43, \quad 9.62 \pm 1.63$ $8.81 \pm 1.50, \quad 8.69 \pm 0.72, \quad 8.20 \pm 0.71$ and $8.00 \pm 0.41$ during $1^{\text {st }}, 2^{\text {nd }}, 3^{\text {rd }}, 4^{\text {th }}, 5^{\text {th }}, 6^{\text {th }}, 7^{\text {th }}$, $8^{\text {th }}, 9^{\text {th }}$ and $10^{\text {th }}$ weeks duration, respectively. The data further indicated that $59.89 \%$ and $66.65 \%$ reduction was examined in treated plots after three and five days Trichogramma chilonis (Ishii.) cards releases respectively as compare to control (untreated) plot. It was observed that Trichogramma chilonis (Ishii.) is useful biological agent for integrated pest management program. According to [20] reported that for the highest yield of parasitoid production, it is important to use younger Trichogramma for parasitization. [21] Achieved superior results with the application of bio-control agents in combination with BT cotton resulting in least infestation by insect pests and maximum seed yield of $3657 \mathrm{~kg} / \mathrm{ha}$. The parasitism percentage of Trichogramma chilonis (Ishii.) was observed significantly higher in bio-control treated conventional cotton. [22] Reported that $H$. armigera population (49.71\%) was notice for variety NIAB-111 in $2^{\text {nd }}$ week (September) and $54.99 \%$ E. insulana were recorded for variety SLH-279 in $1^{\text {st }}$ week (August) compared to NIAB-111 (52.66\%). They recommended that for successful bio-control Trichogramma chilonis (Ishii.) may be used. [23] Showed that integration of bio control agents such as Chrysoperla carnea and Trichogramma chilonis (Ishii.) individually as well as jointly with insecticides proved as effective as chemical control using recommended insecticides against sucking insect pests and spotted bollworms. The integrated control proved economical as it reduced the number of insecticide sprays from 8 in the chemical control to 2 in the integrated control treatments.

\section{Conclusions}

On the basis of the present findings, it was concluded that Trichogramma chilonis may be useful bio-control agent for the integrated pest management program in okra crop. It was further concluded that the okra crop significantly improves the yield per acre by using this biological agent compared to control plot. Trichogramma chilonis is a cheap and economic way for the integrated pest management program. Trichogramma chilonis should be released in okra crop to suppress spotted bollworms.

\section{Authors' contributions}

Conceived and designed the experiments: $\mathrm{S}$ Ahmed, Performed the Experiments: SA Shahwani, S Ahmed \& MA Khetran, Analyzed the Data: S Ahmed \& MI Jakhro Contributed reagents/ Materials/ Analysis tools: M Amin Wrote the paper: S Ahmed \& S Ahmed.

\section{References}

1. Baloch AF (1994). Vegetable crops : Horticulture. National Book Foundation, Islamabad, pp 529-531.

2. Khoso AW (1992). Growing vegetable in Sindh $1^{\text {st }}$, Department of Agronomy Sindh Agriculture University Tandojam: 115-118.

3. Yadav SK \& Dhankar BS (2001). Seed production and quality of okra (Abelmoschus esculentus L.), (Moench) as affected by sowing time and position of fruit on plant. Seed Res 29(1): 47-51.

4. Jagtab CR, Shetgar S S \& Nalwandikar PK (2007). Fluctuation in population of Lepidopterous pest infesting okra in relation to weather parameters during Kharif. Indian J of Entomol 69(3): 218220.

5. Mani M, Krishna MA \& Gopalakrishnan C (2005). Biological control of lepidopterous pests of Horticultural crops in India. A Rev of Agri Res 26(1): 39-49. 
6. Stansly PA, Schuster DJ \& Mc AHJ (1994). Biological control of silver leaf whitefly: An evolving sustainable technology. Proc. $2^{\text {nd }}$ Conf. ASAR, Envir S Agri 484-491.

7. McDougall SJ \& Mills NJ (1997). Dispersal of Trichogramma platneri Nagarkatti (Hymenoptera. Trichogrammatidae) from point-source releases in an apple orchard in California. J of Appl Entomol 121: 205209.

8. Stiling PT \& Cornelissen (2005). What makes a successful biological control agent. A meta-analysis of biological control agent performance. Bio Control 34: 236-246.

9. Collier T \& Van SR (2004). A critical evaluation of augmentative biological control. Biol Control 31(2): 245-256.

10. Van L (1987). Use of Trichogramma species as biocontrol agent. J Adv Zool 4: 71-76.

11. Shahbaz A, Ashfaq M, Mansoor H \& Shahbaz TS (2012). Potential of parasitoid Trichogramma chilonis (Ishii) (Hymenoptera: Trichogrammatidae) against the sugarcane stem borer, Chilo infuscatellus (Lepidoptera: Pyralidae) under field conditions. Inter J Biodiver Conse 4: 36-38.

12. Flanders S \& Quednau W (1960). Taxonomy of the genus Trichogramma (Hymenoptera,

Chalcidoidea, Trichogrammatidae). Biol Control 5: 285-294.

13. Knutson A (2005). A guide to the use of Trichogramma for biological control with special reference to augmentative releases for control of bollworm and budworm in cotton. Tex Agri Exten Ser. B-6071, 5- 98. pp 42.

14. Sumer F, Tuncbilek AS, Oztemiz S, Pintureau B, Rugman JP \&Stouthamer R (2009). A molecular key to the common species of Trichogramma of the
Mediterranean region. Biocontrol 54(1): 617-624.

15. Consoli FL, Parra JRP \& Zucchi RA (2010). Egg parasitoids in agroecosystems with emphasis on Trichogramma. Prog Bio Cont 9(10): 477-482.

16. Henderson CF \& Tilton EW (1955). Tests with acaricides against the brow wheat mite. J Econo Entomol 48(2): 157161.

17. Statistix, 2006. Analytical Software. Statistix 8.1 User's Manual. Analytical Software, Tallahssee (Florida).

18. Phokela A, Dhingra S, Sinha SN \& Mehrotra KN (1990). Pyrethroid resistance in Heliothis armigera Hübner III. Development of resistance in field. Pest Res J 2(1): 28-30.

19. Greathead AH (1986). Host plants. In: Cock MJW (Ed.). Bemisia tabaci FA Literature Survey on the Cotton Whitefly with an Annotated. Bibliography. CAB International Institutes, Biol Control, Silwood Park (UK) pp 17-26.

20. Zahid M, Farid A, Sattar A \& Khan I (2007). Effects of parasitoid and host egg age on parasitism by Trichogramma chilonis (Ishii.) Suranaree J Sci Technol 14(4): 381-384.

21. Ahmad MK\& Ansari BA (2011). Toxicity of neem based pesticide Azacel to the Embryo and fingerlings of Zebrafish. World J Zool 6(2): 47-51.

22. Masood A, Saeed S, Silvaldo DF, Akem CN, Hussain N\& Farooq (2011). Quick decline of mango in Pakistan: survey and pathogenicity of fungi isolated from mango tree and bark beetle. Pak J Bot 43(4): 1793-1798.

23. Mansoor S, Amin I \& Briddon RW (2011). Stress Physiology in Cotton, 7 Ed. Chap8. The Cotton Foundation, Cordova, Tennessee (USA) pp 125-247. 